\title{
Gully erosion as a natural hazard: the educational role of geotourism
}

\author{
Wojciech Zgłobicki • Renata Kołodyńska-Gawrysiak • Leszek Gawrysiak
}

Received: 26 August 2014/ Accepted: 1 November 2014/Published online: 13 November 2014

(C) The Author(s) 2014. This article is published with open access at Springerlink.com

\begin{abstract}
Gully erosion is one of the greatest natural hazards in the loess areas of E. (Eastern) Poland. At the same time, permanent gullies are a major tourist attraction and can provide a basis for the development of geotourism. The study objective was to assess the possibilities of using the loess gullies for educational purposes. Detailed studies were conducted within the municipality of Kazimierz Dolny, an area with an extremely high concentration of permanent gullies. The questionnaire survey of students and tourists (nearly 300 surveys were completed) showed that the respondents' knowledge of geomorphology was limited, despite their familiarity with gullies. In most cases, they were unable to accurately identify the determinants of gully erosion, its negative effects and methods for preventing it. An assessment of the tourism and geotourism potential of the municipality made it possible to identify the sites (gullies) that can perform an educational function, with regard to gully erosion. The establishment of the Małopolska Vistula Gap Geopark, whose highlights will include numerous loess gullies, can pave the way for the development of geotourism.
\end{abstract}

Keywords Education - Geotourism · Gully erosion · Loess areas · E. Poland

\section{Introduction}

Land degradation caused by gully erosion is a serious problem in many areas around the world (Poesen et al. 2006). The formation and development of gullies results in a whole range of phenomena that are unfavourable, from the human perspective; i.e. reduced acreage of cropland, increased risk of flash floods, covering of crops, farms and roads with

W. Zgłobicki $(\bowtie) \cdot$ R. Kołodyńska-Gawrysiak · L. Gawrysiak

Faculty of Earth Sciences and Spatial Management, Maria Curie-Sklodowska University,

Kraśnicka 2d, 20-706 Lublin, Poland

e-mail: wojciech.zglobicki@poczta.umcs.lublin.pl; wojciech.zglobicki@umcs.pl 
silt, and intensive terrain and road network fragmentation (Poesen et al. 2003; Valentin et al. 2005).

The western part of the Lublin Upland (E. Poland) is typified by the occurrence of a very dense network of gullies, whose density exceeds $20 \mathrm{~km} / \mathrm{km}^{2}$ in some places (Gawrysiak and Harasimiuk 2012). At the same time, it is an area where gully erosion has been well researched, over the course of many years. The research has focused on: (1) historical gully erosion (Dotterweich et al. 2012); (2) the dynamics of contemporary gully erosion processes (Rodzik et al. 2009); and (3) the role of gully erosion in land use changes and landscape evolution (Zglobicki and Baran-Zglobicka 2011, 2012).

More and more often, scientific publications take note of the possibility of using geomorphosites in education concerning natural hazards. Increased knowledge among societies about geomorphological processes and their impact on the economy can contribute to reducing the negative effects of these processes, in the future (Coratza and De Waele 2012).

One way to prevent the adverse effects of gully erosion is to educate people about the associated hazards through geotourism. Permanent gullies are an archive (the effect) of processes that occurred within loess areas because of human intervention in the past, as a result of deforestation and agricultural activity (Schmitt et al. 2006; Dotterweich et al. 2012). They constitute a scar on the landscape, but they are also a major tourist attraction in the region. From the perspective of tourists, permanent gullies are currently the most recognisable landforms in the study area (Zgłobicki et al. 2012; Zgłobicki and BaranZgłobicka 2013). This interest in gullies can be used to expand people's knowledge of the mutual relationship between human activity and gullies. A greater awareness of the hazards associated with geomorphological processes will help to reduce the adverse impact of tourist activity and raise public awareness of the impact of gully erosion on human activity.

The study objective was to assess the possibility of using the loess gullies in the Kazimierz Dolny municipality, as a geotourist attraction that would educate tourists about gully erosion. The area has been chosen for detailed study because it is characterised by a very high density of permanent gullies, in comparison with the rest of Poland and Europe. The research procedure encompassed: (1) a review of the state of student and tourist knowledge about gully erosion; (2) a two-stage assessment of the municipality's tourist and geotourist worth; and (3) identifying the gullies most suitable for education.

\section{Study area}

\subsection{Natural environment}

The western part of the Nałęczów Plateau, where the Kazimierz Dolny municipality lies, is typified by the occurrence of a very dense network of permanent gullies (Fig. 1). It is linked to the peculiar, natural conditions occurring here, such as the thick loess layer (up to $30 \mathrm{~m}$ ), large elevation differences (particularly in the Vistula river valley area, where they reach $100 \mathrm{~m}$ ), and a higher frequency of heavy rainfalls (Rodzik et al. 1998). The annual precipitation volume here is $605 \mathrm{~mm}$. In the case of torrential rains, the precipitation volume can reach a maximum of $100 \mathrm{~mm} / 70 \mathrm{~min}$. The landscape in this area has been significantly shaped by many centuries of human activity, notably the deforestation of extensive tracts of land and their transformation into arable land. Consequently, gullies started to form here as early as the Neolithic/Bronze age; the most intensive processes of gully erosion have occurred over the last 1,000 years (Dotterweich et al. 2012). In modern 


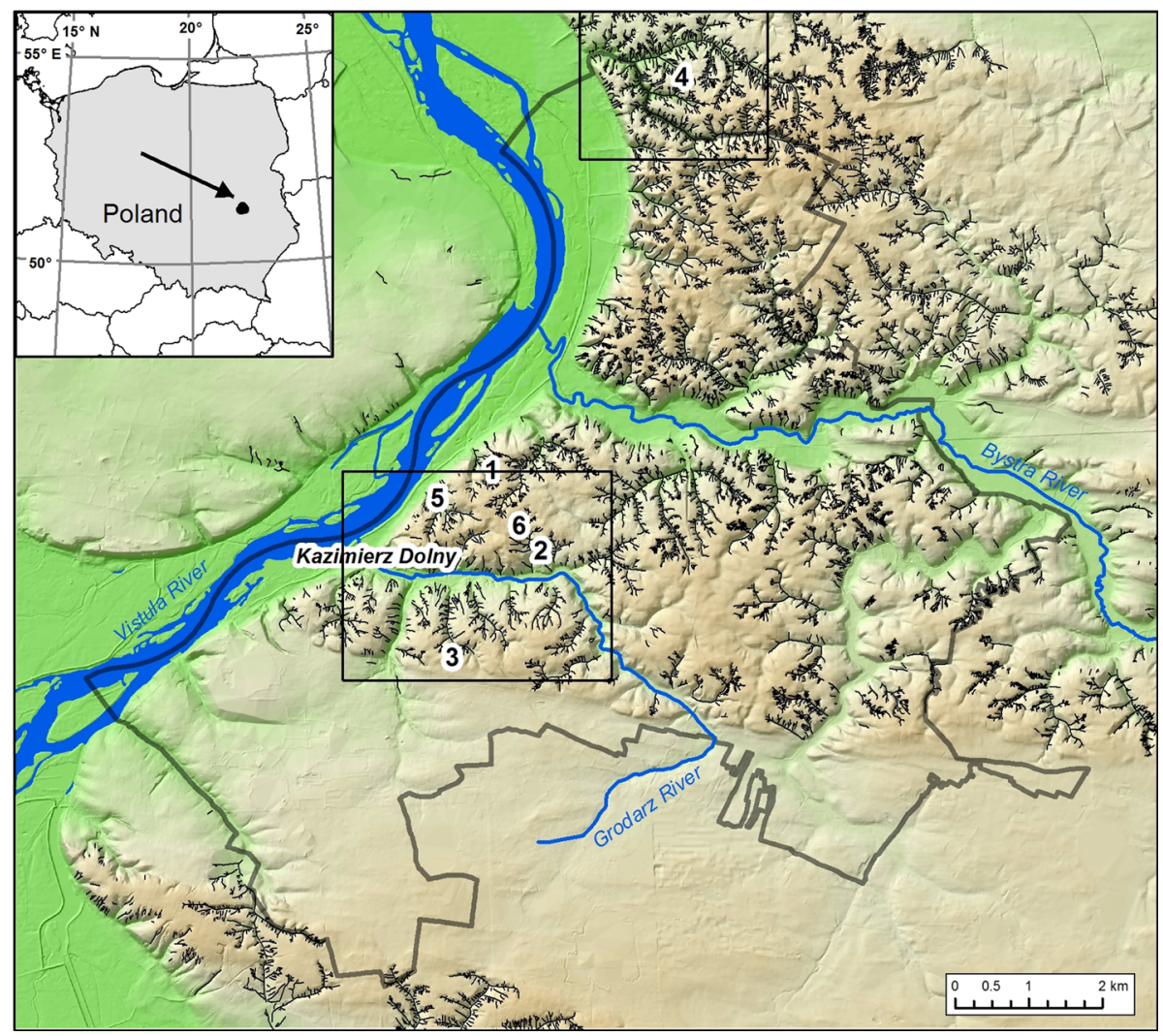

Fig. 1 Permanent gullies in the Kazimierz Dolny municipality. Gullies described in the text: 1-Kamienny Dół, 2-Korzeniowy Dół, 3-Chałajowy Dół, 4-Parchatka, 5-Norowy Dół, 6-Doły Podmularskie. Frames indicate location of maps from Fig. 3

times, forests occur almost exclusively in gullies and on steep slopes, because the relatively fertile Luvisols have already been cultivated over a long period.

The municipality of Kazimierz Dolny is visited by large numbers of tourists, thanks to the occurrence of numerous features linked to geoheritage and culture, as well as flora and fauna. Furthermore, the tourism infrastructure is very well developed. A dense network of tourist trails and a large amount of accommodation and catering facilities are present in the area.

Gullies in the western part of the Nałęczów Plateau typically form multi-branched, dendriform systems, where the total length of all gullies can reach $30-40 \mathrm{~km}$. Large individual gullies are usually several hundred metres long. The length of side gullies ranges from a few to a few dozen metres. The average depth of the gullies is between 10 and $20 \mathrm{~m}$; their width is similar. Their cross-section is close to $\mathrm{V}$ shaped, and the width of the floor ranges from 2 to $4 \mathrm{~m}$. The gully sides are steep $\left(30^{\circ}-40^{\circ}\right)$ or even vertical, in some places. The floor is uneven in the upper reaches of the gullies and in the side gullies. Numerous steps and sinkholes occur here, and the slope of the floor is greater than in the middle and lower reaches of the gullies. The largest gullies dissect the loess cover, and their floors reveal underlying rocks; sand, clay, limestone, and opoka. 
Most forms have the characteristics of semi-natural valley gullies incised into the bottoms of older forms; dry erosion/denudation valleys and denudation troughs. Gullies incised into valley sides occur more rarely. The origins of such gullies are usually linked to the functioning of roads (sunken lanes). The largest forms are straight, 6-8 $\mathrm{m}$ deep, and have a rectangular cross-section.

\subsection{Gully erosion as a natural hazard}

Permanent gullies cover $8 \%$ of the Kazimierz Dolny municipality, which results in the exclusion of at least $10 \%$ of the area from agricultural use. The existence of gullies hinders access to fields and is not conducive to land consolidation processes (BaranZgłobicka and Zgłobicki 2012). Most gullies are no longer active, even though for $20 \%$ of their length there is a risk of erosion processes being reactivated, due to the agricultural use of areas immediately adjacent to the gully edges.

The most intensive gully erosion processes occur during torrential rainfall (rain intensity more than $1 \mathrm{~mm} / \mathrm{min}$.) when arable fields and gully floors are subjected to strong erosion. The eroded material amounts to several thousand tonnes per square kilometre of a gully catchment (Maruszczak 1986). Intensive snow melt in the spring and heavy rainfall (rain intensity $\leq 1 \mathrm{~mm} / \mathrm{min}$ ) in the summer occur more often, but their geomorphological significance is smaller (Rodzik et al. 1998; Gardziel et al. 2006).

Intensive gully erosion processes pose a serious hazard to infrastructure, particularly to dirt roads, that can become partially or totally impassable. Erosion causes large amounts of material to be transported to the floors of valleys of a higher order, where metalled roads are usually built. As a result, these roads are covered with silt and, in extreme cases, are also rendered impassable. Alluvial fans that suddenly accumulate at the mouths of gullies also become a major obstacle to the flow of episodic waters and proper drainage of roads. As human settlements are concentrated in the valley floor, farms and urban areas (Kazimierz Dolny) are also covered with silt (Gardziel et al. 2006).

It should be stressed that the contemporary dynamics of gully erosion is determined, to a very large extent, by the character of agricultural activity. The intensity of erosion processes is impacted by the type of land use in gully catchments, i.e. land cover and field patterns. A large share of arable land and plantations in a catchment, as well as the perpendicular orientation of plots to the gully edge, is conducive to episodic run-off and gully erosion (Rodzik et al. 2009).

\section{Methods}

In order to examine the level of knowledge on gully erosion and its associated hazards, a questionnaire survey was carried out among the students of the UMCS Faculty of Earth Sciences and Spatial Management. In the future, some of the respondents may become experts who will influence the prevention of the adverse effects of gully erosion. The student questionnaire contained 13 questions (Appendix 1). An online survey was also conducted among tourists, in order to find out what the public thinks of gullies. The request to complete the survey was posted to the following newsgroups 'pl.rec.rowery', 'pl.rec.gory', and 'pl.regionalne'. The online survey was shorter and simpler; containing ten questions (Appendix 2).

The selected features of the tourism potential of the Kazimierz Dolny municipality were also assessed based on the following criteria: gully density, elevation differences, land 
Table 1 Tourism assessment criteria for the Kazimierz Dolny municipality

\begin{tabular}{|c|c|c|c|}
\hline Criterion & Unit & Range & Score \\
\hline Gully density & $\mathrm{km} / \mathrm{km}^{2}$ & $0-20$ & $0-5: 0 \mathrm{pts} ; 5.1-10: 0.5 \mathrm{pts} ; 10.1-15: 1.0 \mathrm{pts} ;>15.1: 1.5 \mathrm{pts}$ \\
\hline Tourist trails & Number & $1-10$ & $0-3: 0 \mathrm{pts} ; 3.1-5: 0.5 \mathrm{pts} ; 5.1-7: 1.0 \mathrm{pts} ; 7.1-10: 1.5 \mathrm{pts}$ \\
\hline Elevation differences & $\mathrm{m}$ & $10-100$ & 10-30: $0 \mathrm{pts} ; 31-60: 0.5 \mathrm{pts} ;>61: 1.0 \mathrm{pts}$ \\
\hline Land cover mosaic & Number & $1-6$ & 1-2: 0 pts; $3-4: 0.5$ pts; $5-6: 1.0$ pts \\
\hline Road density & $\mathrm{km} / \mathrm{km}^{2}$ & $2-20$ & $0-5: 0 \mathrm{pts} ; 5.1-10: 0.5 \mathrm{pts} ;>10: 1.0 \mathrm{pts}$ \\
\hline
\end{tabular}

cover mosaic, road network, tourist trails, and educational paths (Table 1). The criteria above have an impact on attractiveness to tourists and accessibility to the study area. Computations were carried out for hexagons covering $1 \mathrm{~km}^{2}$. The assessment was conducted using layers (maps) containing data related to the criteria mentioned above. The source data were obtained from 1:10,000 topographical maps (gullies, roads), a digital terrain model (elevation differences), Corine Land Cover (land cover mosaic), and tourist maps (tourist trails and educational paths). In all cases, a greater index value resulted in a higher number of points being scored (Table 1).

We also used source data obtained for the purposes of another study assessing the geotourist value of geomorphosites (Warowna et al. 2014). The assessment took into account 18 criteria, making up five groups of values: scientific, educational, functional, environmental protection, and tourist values (Table 2). The data used in the study concerned the values for 15 gullies located in the Kazimierz Dolny municipality, having the status of geosites and listed in Poland's Central Register of Geosites.

\section{Results}

\subsection{Questionnaire survey}

A total of 284 questionnaires were collected, including 228 completed by students attending four different courses of study: geography ( $27 \%$ of the questionnaires); geoinformatics $(22 \%)$; spatial management (31\%); and tourism and recreation $(20 \%)$. A greater proportion of the students surveyed were women $(58 \%)$ while men were a clear majority among the tourists $(73 \%)$. Differences also occurred with regard to place of residence. Tourists who responded to the survey mostly came from large towns $(70 \%)$ while $47 \%$ of the students surveyed came from rural areas. The term "loess gully" was known to $86 \%$ of students and $63 \%$ of tourists. The students visited the gullies more often than the tourists. 54 and $44 \%$, respectively, of respondents said they had visited a gully more than three times in their life. Responses relating to the characteristic features of gullies were similar for both groups: (1) steep slopes (29\% of students and $24 \%$ of tourists); (2) narrow floor (16\% of students and $19 \%$ of tourists); (3) dry floor (17\% of students and $15 \%$ of tourists); and (4) covered by forest (14\% of both students and tourists). As many as $8 \%$ of tourists, compared to a mere $1 \%$ of students, indicated that gullies are used agriculturally.

Respondents considered that human impact on the formation of gullies is moderate (48\% of students) or small (35\% of tourists). The answer, "I do not know" was also frequent (19\% of students and $27 \%$ of tourists). 
Table 2 Details of the geotourist assessment of gullies-criteria and scores (after Kubalikova 2012, modified)

\section{Scores}

Scientific value

Scientific knowledge

Rarity

Diversity

Degree of degradation

Educational value $t$

Representativeness

Educational use

Existing educational products
0.0 - None

0.25 -Local publications

0.5 -Regional publications

0.75-National publications

1.0-A lot of scientific information, international publications

0.0 - Is not among the top 5 most important sites

0.25 - Is not among the top 3 most important sites

0.50 - One of the 3 most important sites

0.75 -Very important

1.0 - The only occurrence

0.0 - Only one abiotic feature (process)

$0.25-2$ abiotic features

$0.5-3$ abiotic features

$0.75-4$ abiotic features

$1.0-5$ and more

0.0 - Highly degraded by human activity

0.25 -Degradation caused by natural processes

0.50—Degraded but significant geomorphological/ geological features are preserved

0.75-Slightly degraded, significant geomorphological/ geological features are visible

1.0- Lack of visible degradation

0.0-Very low representativeness/poor visibility of features

0.25 -Low

0.5 -Medium (primarily for experts)

0.75 - High

1.0 - Very high (also for non-experts)

0.0 - Unused and unpromoted

0.25 -Used sporadically by specialists

0.50 - Used for teaching purposes

0.75 -Used as a site of special scenic value

1.0 - Used as a geosite

0.0 - None

$0.25-1$ kind of promotion and 1 product

$0.50-1$ kind of promotion and several products

0.75-May kinds of promotion and 1 product

1.0-Many kinds of promotion and many products 
Table 2 continued

Scores

\section{Functional value $t$}

Accessibility

Presence of tourist infrastructure (accommodation, restaurants)

Local products

Environmental protection value $t$ Legal protection status

Current status of the site

Current and potential risks

Ecological value

\section{Tourist value $t$}

Cultural value
0 - Accessible by car and more than $1,000 \mathrm{~m}$ walking distance

0.25 -Accessible by car and $<1,000 \mathrm{~m}$ walking distance

0.50 - Accessible by car and $<500 \mathrm{~m}$ walking distance

0.75 -Accessible by public transport and more than $500 \mathrm{~m}$ walking distance

1.0 - Accessible by public transport and $<500 \mathrm{~m}$ walking distance

0.0 -More distant than $25 \mathrm{~km}$

0.25 -Between 10 and $25 \mathrm{~km}$

0.50 -Between 5 and $10 \mathrm{~km}$

0.75 - Place to stay or place to eat $<5 \mathrm{~km}$ away

1.00 - Place to stay and place to eat $<5 \mathrm{~km}$ away

0.0 - No products associated with the site

0.5 -Several products

1.0 - Some products are emblematic for the area

0.0 - None

0.25 - Area of protected landscape, ecological land

0.50 -Landscape park, study site

0.75 -Natura 2,000

1.0- Protected site (national park, nature reserve, site of natural interest)

0 - Total protection and prohibited use

0.25 - Protection and restricted use

0.50 - Protection but no restrictions on use

0.75 - No protection but restricted use

1.00 - No protection and no restrictions on use

0.0 - Irreversible (possibility of total loss)

0.25 - High (could be easily damaged)

0.5 -Medium (could be damaged by natural processes or human activities)

0.75 - Low (could be damaged only by human activities)

1.0 - None

0.0 - No association with the biotic aspects

0.25 -Occurrence of interesting fauna and/or flora

0.50 - One of the best sites for watching interesting fauna and/or flora

0.75-The geomorphological characteristics are significant for the ecosystem

1.0- The geomorphological characteristics determine the ecosystem

0.0—No cultural features 
Table 2 continued

\begin{tabular}{|c|c|}
\hline & Scores \\
\hline & $\begin{array}{l}0.25 \text {-Cultural features not associated with the features of } \\
\text { the site }\end{array}$ \\
\hline & $\begin{array}{l}0.50 \text { - Intangible cultural phenomena associated with the } \\
\text { site }\end{array}$ \\
\hline & $\begin{array}{l}0.75 \text {-Tangible cultural phenomena associated with the } \\
\text { site }\end{array}$ \\
\hline & $\begin{array}{l}\text { 1.00-Significant tangible cultural phenomena associated } \\
\text { with the site }\end{array}$ \\
\hline \multirow{5}{*}{$\begin{array}{l}\text { Additional attractions (a } 30 \text { min walk away or } \\
\text { up to } 5 \mathrm{~km} \text { by car) }\end{array}$} & 0.0 -None \\
\hline & 0.25 -Only animate nature \\
\hline & $\begin{array}{l}0.5 \text {-Animate nature and anthropogenic (cultural } \\
\text { attractions) }\end{array}$ \\
\hline & 0.75 -Another geosite or interesting abiotic site \\
\hline & $\begin{array}{l}\text { 1.0-Abiotic, biotic and cultural sites, geosites in close } \\
\text { proximity }\end{array}$ \\
\hline \multirow[t]{3}{*}{ Aesthetic value } & 0.0 - Single colour \\
\hline & $0.5-2$ to 3 colours \\
\hline & 1.0-More than 3 colours \\
\hline \multirow[t]{5}{*}{ Viewpoints } & 0.0 - Site not well visible \\
\hline & 0.25 -Visibility reduced by trees or lower plants \\
\hline & $\begin{array}{l}0.50 \text { - Good visibility but walking all around the site is } \\
\text { required for full observation }\end{array}$ \\
\hline & 0.75 -Good visibility of all significant geotourist features \\
\hline & $\begin{array}{l}\text { 1.0-Excellent visibility of all significant geotourist } \\
\text { features }\end{array}$ \\
\hline
\end{tabular}

Asked to indicate areas in Poland with the highest concentration of gullies, most of the tourists mentioned uplands $(47 \%)$ and the Beskidy Mountains $(24 \%)$. The students, on the other hand, indicated the Kazimierz Dolny area as having the highest concentration of gullies in the Lublin region (80\%). Only $7 \%$ mentioned the Szczebrzeszyn area, where the gully density is actually similar to that of Kazimierz Dolny.

Asked to name a process leading to the formation of gullies, students mentioned episodic run-off in forest areas (44\%), the activity of rivers $(21 \%)$, and episodic run-off in agricultural areas $(18 \%)$. With regards to the most significant factors influencing the formation of gullies, students mentioned the type of soil and substratum (54\% of answers, score 4 and 5), annual precipitation volume (46\%), and land relief (41\%). The abovementioned question was absent in the questionnaire for tourists.

Most of the students and tourists were unable to assess the significance of gully erosion to human activity. $41 \%$ of students and $44 \%$ of tourists replied, "I do not know". The negative aspect of the existence of gullies was indicated by $33 \%$ of students and $24 \%$ of tourists, while the positive aspect was indicated by 15 and $9 \%$, respectively.

Students mentioned the reduced acreage of fields (32\%) and silting up of roads, farms, and fields $(31 \%)$ as the most negative effects of gully erosion. Deforestation and use of gullies as dirt roads were indicated as the key factors increasing the intensity of gully erosion. This answer was given by 28 and $22 \%$ of respondents, respectively. 
According to respondents (51\% of students and $63 \%$ of tourists), the reforestation of the gullies and adjoining areas is the best method to prevent gully erosion. Quite frequently, students also mentioned an appropriate field and crop pattern in the neighbourhood of gullies (29\%).

$87 \%$ of students and $72 \%$ of tourists regarded gullies as a tourist attraction. From the perspective of the tourist function, the following key characteristics of gullies were indicated: gullies are a good place for walks and they feature varied, natural landscapes.

Nearly, half of the tourists surveyed had not visited the Kazimierz Dolny area over the past 5 years. Among students, most respondents had visited the area for tourist purposes, once or twice. In both groups, the proportion of persons who had been here more than five times was similar (12-13\%).

\subsection{Tourism and geotourism assessment}

The results of the tourism assessment of the municipality made it possible to identify areas of high tourism value (gully density, elevation differences and land cover mosaic) and accessibility (road and tourist trail network). These areas are located in the lower reaches of the Grodarz catchment, the lower reaches of the Bystra catchment, and the northern part of the municipality (Fig. 2). They primarily include the steep sides of river valleys, within which the assessed indicators reached a high level.

The following gullies in the Kazimierz Dolny municipality show the highest geotourism value: (a) Kamienny Dół; (b) Korzeniowy Dół; (c) Parchatka; (d) Doły Podmularskie; (e) Norowy Dół, and; and (f) Chałajowy Dół. All of them are characterised by high scientific value, including numerous scientific publications, and usually easy access. Some of the gullies have a limited educational value, due to the lack of interpretation boards explaining their geoheritage value (Table 3 ).

\subsection{Accessibility of gullies to tourists}

Although gullies are a landmark of the Kazimierz Dolny municipality, they are accessible and used for tourism purposes only to a limited extent. While the length of the gullies here amounts to $343 \mathrm{~km}$ (Table 4), slightly less than a quarter $(79 \mathrm{~km})$ are accessible to tourists (i.e. used as roads). Accessibility of the gullies is determined by natural conditions (morphology, vegetation, hydrography) and the historical pattern of roads and paths that often run through the bottoms of gullies, helping local people move between their homesteads in the valleys and the arable fields located on the vast and fertile loess plateau tops.

Sunken lanes are the most accessible, as they allow both pedestrian and vehicle transport. Semi-natural gullies are typified by a greater variation of tourist accessibility, determined by a variety of natural environment characteristics even within a single gully system. Therefore, pedestrian trails can usually be found in these gullies (KołodyńskaGawrysiak et al. 2012).

Hiking and bicycle trails have been established along approximately $23 \mathrm{~km}$ of gullies (Table 4), which accounts for a little more than a third of all accessible gullies. They are usually part of long-range tourist trails, including supra-regional trails. Furthermore, some gullies or some stretches of gullies are part of educational paths that present the region's geological, biotic, and cultural values alongside subjects related to gully erosion. 


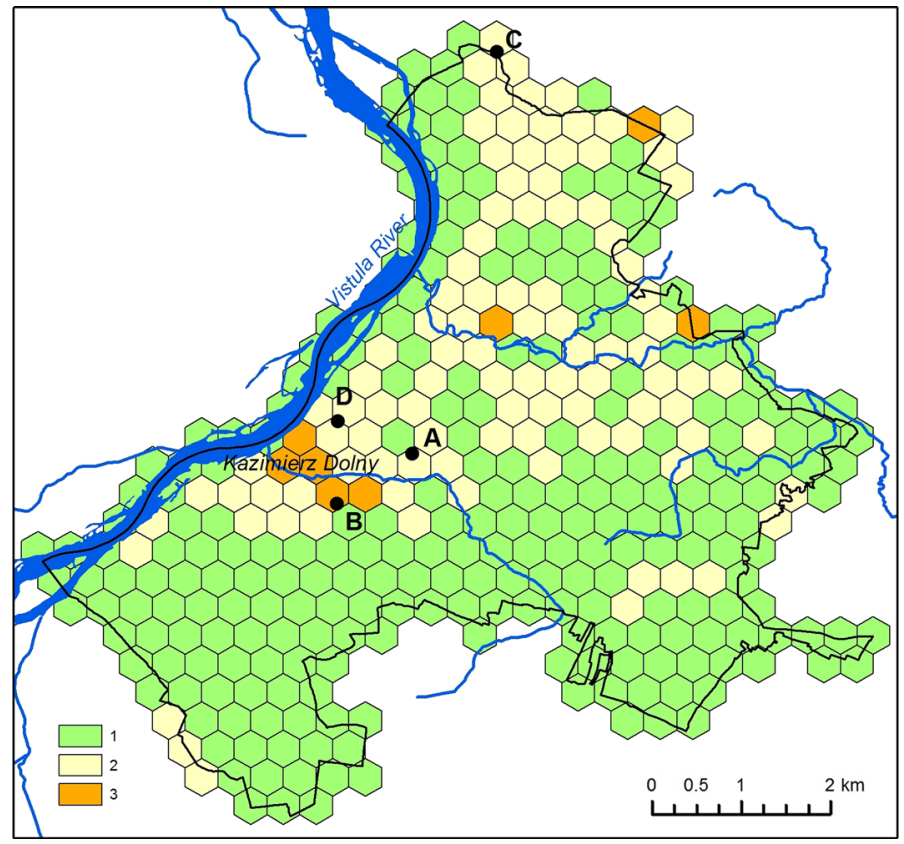

Fig. 2 Results of the tourism assessment for the Kazimierz Dolny municipality and location of gully systems proposed for development of geotourism. 1-low value, 2-moderate value, 3-high value, a Korzeniowy Dół-Doły Podmularskie, b Chałajowy Dół, c Gully system in Parchatka, d Norowy Dół

Table 3 Gullies with the highest geotourist value (in the Kazimierz Dolny municipality)

\begin{tabular}{llllllc}
\hline Gully & Scientific & Educational & $\begin{array}{l}\text { Value } \\
\text { functional }\end{array}$ & $\begin{array}{l}\text { Environmental } \\
\text { protection }\end{array}$ & Tourist & $\begin{array}{l}\text { Overall } \\
\text { value }\end{array}$ \\
\hline Kamienny Dół & 3.5 & 3.0 & 2.5 & 2.0 & 2.25 & 13.25 \\
$\begin{array}{l}\text { Korzeniowy } \\
\quad \text { Dół }\end{array}$ & 3.25 & 3.0 & 2.0 & 2.5 & 2.25 & 13.0 \\
$\begin{array}{l}\text { Parchatka } \\
\text { Doły }\end{array}$ & 3.0 & 2.25 & 2.0 & 2.5 & 1.5 & 11.25 \\
$\quad$ Podmularskie & 3.25 & 1.25 & 2.0 & 2.5 & 1.5 & 10.5 \\
$\begin{array}{l}\text { Norowy Dół } \\
\text { Chałajowy Dół }\end{array}$ & 2.0 & 1.75 & 2.5 & 2.5 & 1.0 & 9.75 \\
$\begin{array}{l}\text { Maximum } \\
\text { value }\end{array}$ & 4 & 1.5 & 1.5 & 1.0 & 0.75 & 8.5 \\
\hline
\end{tabular}

\subsection{Proposed geotourist trails in the Kazimierz Dolny municipality}

Although several educational paths have been designated in the Kazimierz Dolny municipality, none of them has the character of a geotourist trail presenting the problems of gully erosion. The existing extensive scientific documentation on a range of gully-related issues can provide the basis for establishing a geoeducational trail presenting gully erosion 
Table 4 Selected characteristics of accessibility and tourism development of gullies in the Kazimierz Dolny municipality

\begin{tabular}{lc}
\hline Selected gully characteristics & Value \\
\hline Gully density $\left(\mathrm{km} / \mathrm{km}^{2}\right)$ & 6.11 \\
Length of gullies $(\mathrm{km})(d)$ & 343.0 \\
Length of roads in gullies $(\mathrm{km})(r)$ & 79.0 \\
Length of tourist trails in gullies $(\mathrm{km})(t)$ & 23.1 \\
Gully accessibility index $(D=r / d)$ & 0.23 \\
Tourism accessibility index of gullies $(U=t / d)$ & 0.06 \\
\hline
\end{tabular}

as a natural hazard (Fig. 3; Table 5). The designated sites have the following characteristics, that are significant from the perspective of tourism: (1) short distance from the centre of Kazimierz Dolny; (2) easy access by asphalt road; (3) short length of the trail (about 3-4 km); (4) a wide range of subjects involved; (5) good accessibility of the gullies; and (6) the very high attractiveness to tourists of some of the gullies (Korzeniowy Dó1, Kamienny Dół). All the trails (sites) are located in areas of the highest tourist value (Fig. 2). Gullies offer an opportunity to present a wide range of geological and geomorphological subjects in conjunction with hiking tourism (Fig. 4). The following key phenomena and processes associated with gullies and gully erosion can be presented, based on the selected geosites: (1) geological structure of the substratum: Quaternary and older; (2) loess characteristics; (3) contemporary geomorphological processes; (4) historical gully erosion; (5) human impact on the formation of gullies (field pattern and road network); and (6) evolution of landscape under anthropogenic pressure (Table 5).

The following subjects directly associated with gully erosion can be presented along the proposed trails:

a Korzeniowy Dół-Doły Podmularskie (duration of the walk: 2 h): the pace of sunken lane development, modern-day development of gullies, human impact on gully development in prehistoric and historic times;

b Chałajowy Dół (duration of the walk: $1.5 \mathrm{~h}$ ): types of processes modelling the gullies, impact of piping on gully development, morphological effects of piping and erosion, impact of the field pattern on gully development, impact of land morphology on the development of sunken lanes, phases of gully erosion;

c Gully system in Parchatka (duration of the walk: about 2-3 h): prehistoric and historic human settlement, development of permanent gullies forming an extremely dense system (more than $20 \mathrm{~km} / \mathrm{km}^{2}$ ), effects of gully erosion on infrastructure, hazards linked with the reactivation of erosion processes (tree felling, excessive growth of tourism and recreation);

d Norowy Dół (duration of the walk: about 2 h): soil type mosaic as a result of erosion in loess areas with varied relief, erosion prevention measures and their performance.

It is particularly important to make visitors aware that the formation of gullies is directly linked to human activity. Had it not been for deforestation and the development of agriculture, such a multitude of gullies would not exist. Human activity plays a significant role in the transformation of gullies, in modern times as well: the felling trees in gullies and the cultivation of fields immediately adjoining the gullies can lead to the reactivation of gully erosion processes and negative effects for local people. 

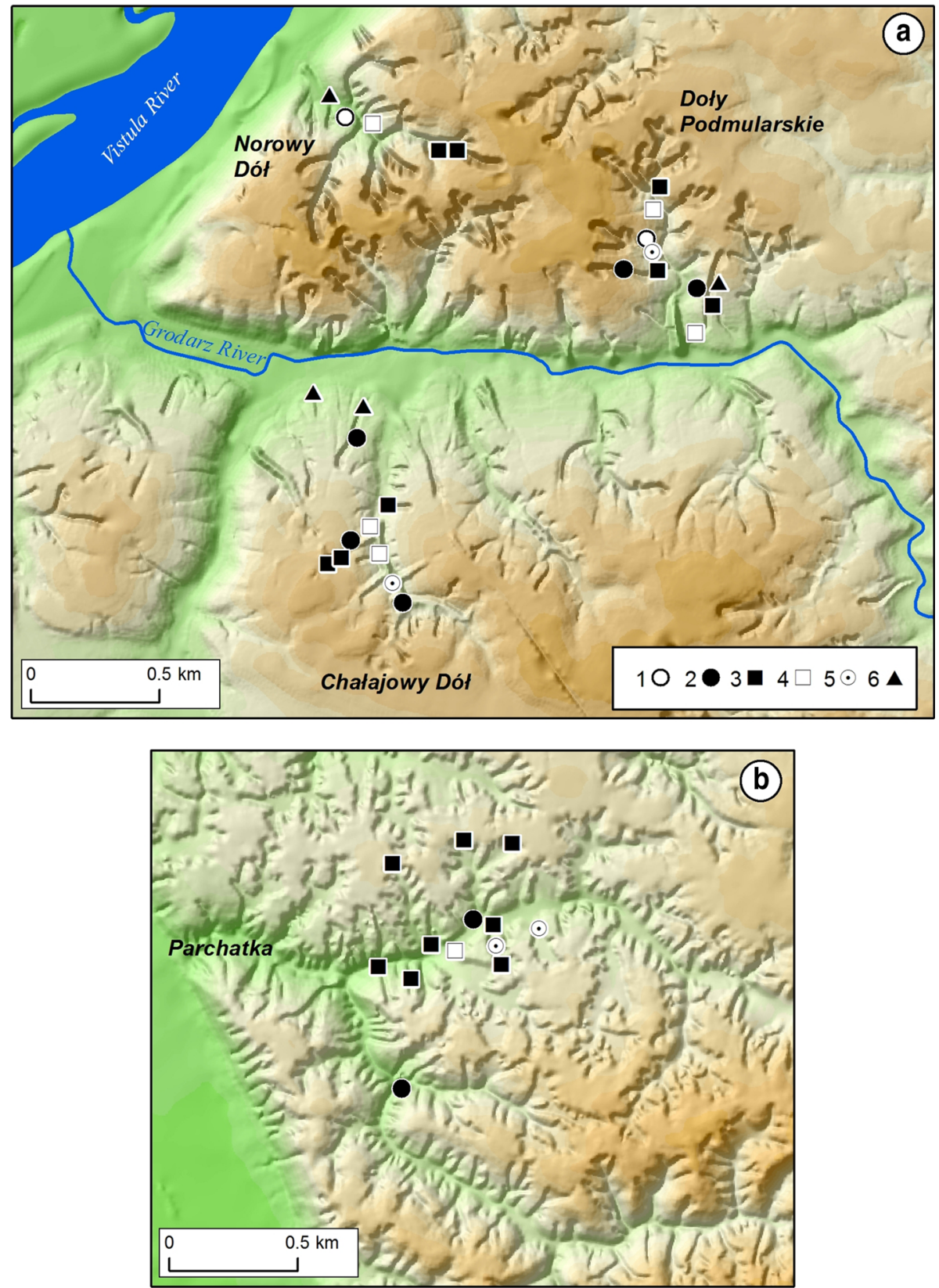

Fig. 3 Location of sites of geotourist value in the gully region of Kazimierz Dolny. a Korzeniowy DółDoły Podmularskie, Chałajowy Dół and Norowy Dół gullies, b lower part of gully system in Parchatka. Geotourist resources: 1-outcrops of under loess bedrock, 2-outcrops of loess and loess colluvia, 3interesting forms of relief, 4-active erosion processes, 5-hydrogeological sites, 6 anti-erosion measures 
Table 5 Problems of gully erosion as a natural hazard based on the proposed geotourist trails

\begin{tabular}{lll}
\hline Problems & $\begin{array}{l}\text { Identification of } \\
\text { geomorphological processes }\end{array}$ & $\begin{array}{l}\text { Noteworthy characteristics of } \\
\text { relief }\end{array}$ \\
\hline
\end{tabular}

(A) Korzeniowy Dót, Doty Podmularskie gullies

Loess characteristics

Types and structure of soils developed from loess

Processes shaping the gullies

Key genetic types of gullies

Erosion prevention measures

Historical gully erosion

(B) Chałajowy Dót gully

Loess characteristics

Types and structure of soils developed from loess

Processes shaping the gullies

Hazards to agriculture resulting from an inadequate land use structure (types of crops, field pattern) in the vicinity of gullies

Key genetic types of gullies

Erosion prevention measures

Hazards to infrastructure resulting from gully erosion

Impact of the area's morphology on the development of road gullies
Lithological characteristics of loess reflecting its aeolian origins

Lessivage process recorded in the morphology of Luvisols

Alternating stages of erosion (deepening) and raising of the gully floor (accumulation)

Landslide processes modelling the gully sides

Piping processes initiating the development of gullies

Spatial variation of erosion and accumulation processes within a gully system

Reinforcing the floor of a road gully to minimise rill erosion

Colluvial sediment profile resulting from several stages of erosion and accumulation

Lithological characteristics of loess reflecting its aeolian origins

Lessivage process recorded in the morphology of Luvisols

Alternating stages of erosion (deepening) and raising of the gully floor (accumulation)

Landslide processes modelling the gully sides

Piping processes initiating the development of gullies

Development of piping and erosion at the boundary between agricultural plots and gully edges

Spatial variation of erosion and accumulation processes within a gully system

Reinforcing the floor of a road gully to minimise rill erosion

Accumulation of colluvial sediments at the mouth of a road gully

Variation of erosion intensity depending on the slope gradient
Loess walls up to $8 \mathrm{~m}$ high, presenting the homogeneous structure of loess

Exposed profiles of Luvisols

Systems of terraces and falls in the gully floor

Landslides within the steep gully sides

Piping sinkholes in the upper reaches of young gullies

Various types of gullies including a typical, V-shaped gully and a road gully

Typical road gully with a low dynamics of processes

Fossil gully filled with sediments

Loess walls up to $7 \mathrm{~m}$ high, presenting the homogeneous structure of loess

Exposed profiles of Luvisols

Systems of terraces and falls in the gully floor

Landslides affecting the steep gully sides

Piping sinkholes in the upper reaches of young gullies

Piping sinkholes, complex of young gullies (badlands)

Various types of gullies including a typical, V-shaped gully and a road gully (sunken lane)

A disused road gully

Alluvial fan forming periodically on the surface of a metalled road

Stretches of a gully characterised by varying depth 
Table 5 continued

Problems
Springs in gullies
(C) Gully system in Parchatka

Stages of gully development recorded in its morphology

Springs in gullies

Fossil springs

Prehistoric settlement and land use in the vicinity of the gully and possible initiation of prehistoric gully erosion

Erosion-related hazards to recreation infrastructure

Hazards to gullies related to the development of recreation

Impact of inappropriate land use in gullies on the development of erosion

(D) Norowy Dót gully

Loess characteristics

Types and structure of soils developed from loess

Key genetic types of gullies

Erosion prevention measures in the gully floor

Hazards to infrastructure resulting from gully erosion
Identification of

geomorphological processes

Noteworthy characteristics of relief

Outflow of water at the boundary of lithological layers

Stretches of a gully with a predominance of erosion or accumulation in the gully floor and active or stable sides

Outflow of water at the boundary of lithological layers

Process of travertine formation

Potential conditions for the initiation of gully erosion processes as a result of deforestation by the first agricultural cultures

Degradation of a ski slope due to the development of the upper reaches of a gully

Erosion and accumulation of episodic water on the gully floor

Degradation of the gully floor and gully sides by all-terrain vehicles and quads

Initiation of gully erosion by contemporary forest felling

Lithological characteristics of loess reflecting its aeolian origins

Lessivage process recorded in the morphology of Luvisols

Spatial variation of erosion and accumulation processes within a gully system

Development of rill erosion with a periodically extreme character despite the prevention measures used (historical documentation)

Accumulation of colluvial sediments at the mouth of a gully
Springs emerging from the base of a gully side

Morphological types of gullies corresponding to the stage of their development

Springs emerging from the base of a gully side

Travertine in a gully as evidence of the outflow of water in the past

Unique characteristics of relief that determined the location of human settlements

Active gully encroaching the ski slope area

Elements of infrastructure protecting against the effects of episodic outflow from the gully floor

Deep ruts left by all-terrain vehicles and quads

Erosional rills forming in areas cleared of forest

Loess walls up to $4 \mathrm{~m}$ high, presenting the homogeneous structure of loess

Exposed profiles of Luvisols

Various types of gullies including a typical, V-shaped gully and a road gully

Channel of an episodic stream

Alluvial fan at the mouth of a gully 
Table 5 continued

\begin{tabular}{|c|c|c|}
\hline Problems & $\begin{array}{l}\text { Identification of } \\
\text { geomorphological processes }\end{array}$ & $\begin{array}{l}\text { Noteworthy characteristics of } \\
\text { relief }\end{array}$ \\
\hline $\begin{array}{l}\text { Impact of the area's lithology and } \\
\text { morphology on the development } \\
\text { of road gullies }\end{array}$ & $\begin{array}{l}\text { Variation of erosion intensity } \\
\text { depending on the rock lithology } \\
\text { and slope gradient }\end{array}$ & $\begin{array}{l}\text { Stretches of a gully characterised } \\
\text { by varying depth and gradient of } \\
\text { its floor. Stretches of the gully } \\
\text { floor with a lower gradient } \\
\text { accompanying outcrops of } \\
\text { glacial till. Stretches with a } \\
\text { greater depth develop where the } \\
\text { dissected slope is steeper and } \\
\text { where loess occurs. }\end{array}$ \\
\hline The shaping of gully sides & The impact of piping processes & Complex of piping sinkholes \\
\hline $\begin{array}{l}\text { Morphology of the loess plateau } \\
\text { top }\end{array}$ & $\begin{array}{l}\text { Processes of loess accumulation, } \\
\text { postglacial denudation as a } \\
\text { result of natural and } \\
\text { anthropogenic factors }\end{array}$ & $\begin{array}{l}\text { Area of aeolian accumulation, } \\
\text { closed depressions, denudation } \\
\text { troughs }\end{array}$ \\
\hline $\begin{array}{l}\text { Soil erosion hazards resulting } \\
\text { from intensive tillage in loess } \\
\text { areas of varied relief }\end{array}$ & $\begin{array}{l}\text { Spatially varied processes of soil } \\
\text { erosion }\end{array}$ & $\begin{array}{l}\text { Cultivated terraces and soil type } \\
\text { mosaic as a result of erosion }\end{array}$ \\
\hline
\end{tabular}

\section{Discussion}

\subsection{Educational role of geotourism}

The problem of using loess landscape for tourism purposes has already been described in literature (Dong et al. 2014; Solarska et al. 2013). However, the main issue discussed has been the role of loess as an archive of changes in the environment and loess landscape characteristics. Loess profiles have been the most frequently described geosites. Gullies have been mentioned as an important landform in loess areas, but they have not been regarded as geotourist sites that can serve educational purposes.

The development of geotourism occurs primarily within the geoparks and geosites designated there (Serrano and Gonzales-Trueba 2005; Farsani et al. 2014); a special role can be played by geomorphosites (Thomas 2012). The possibilities of using geomorphosites in geomorphology education are presented by Coratza and De Waele (2012). Taking the example of Italy, they describe sites (landforms) that could be used to raise public awareness of natural hazards. The authors mention processes such as earthquakes, landslides, flash floods, volcanic events, and tsunamis. Databases and Internet portals devoted to natural hazards play a very important role in education (Dunbar 2007). In Poland, such a key role can be played by the Polish Central Register of Geosites. Although it contains only landforms, not processes or phenomena, it seems that it could be a useful database, on a regional scale (Warowna et al. 2013).

The results of these surveys clearly reveal an insufficient level of knowledge about the determinants of gully erosion, human impact on the intensity of the process, and the significance of the existence of gullies to humans. In many cases, the respondents were either unable to give an answer or their answers were incorrect. At the same time, more than half of the respondents had visited loess gullies several times. In the case of students, the frequency of visits was high. One cannot rule out that in some cases, respondents' answers reflect perceptions, rather than real knowledge. Additionally, the format of the survey, where the respondents choose from suggested answers, could impact on results pertaining to respondents' knowledge. 

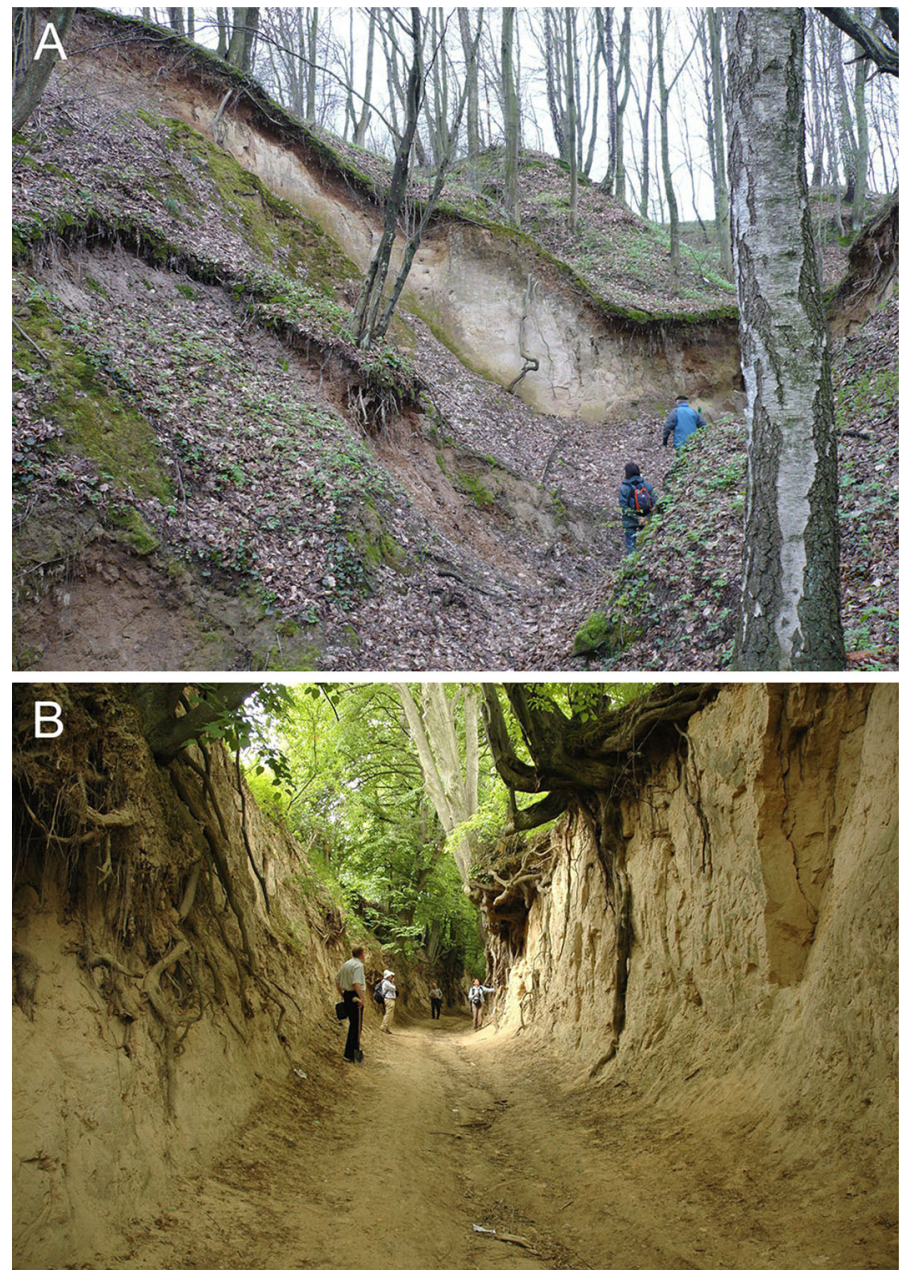

Fig. 4 Loess gullies. a Doły Podmularskie, b Korzeniowy Dół

Knowledge among individuals who had not visited the gullies was considerably more limited than among those who have been there more than three times. In the case of the former, the answer "I do not know" was chosen much more often (up to twice as often). The very fact of visiting a gully could have influenced understanding of the processes occurring in it and their interaction with human activity. This indicates the important educational role of visits to gullies.

\subsection{The tourist and educational value of gullies in the Kazimierz Dolny municipality}

In our opinion, gullies in the Kazimierz Dolny municipality are characterised by exceptional natural environment features offering a wide range of uses in geoeducation, tourism and recreation. This follows primarily from the typological diversity of gullies, with regard to their origin, morphological characteristics, and development phases. In the gullies, one can also observe the effects of morphogenetic processes occurring at different times, i.e. in 
the present, as well as several hundred and even thousands of years ago (Dotterweich et al. 2012). This, in turn, makes it possible to assess the development rate of erosion processes and landforms, from the temporal perspective. It also enables the correlation of the main gully development phases with characteristics of the economy and stages in the economic development of the region. Gully erosion in the Kazimierz Dolny municipality has always been a serious problem, in terms of its adverse economic impact, particularly on infrastructure. Therefore, one can observe and assess the efficiency of individual erosion prevention measures applied mainly in the sunken lanes of the study area (Gardziel et al. 2006). The effects of the erosion processes documented by scientists in gullies and their vicinity (often having an extreme character) constitute a valuable source of information on the geohazards associated with gully erosion (Dotterweich et al. 2012; Rodzik et al. 2009).

Due to the large diversity of the morphometric characteristics of gullies, particular forms, or their systems, they have features suitable for the development of various forms of soft adventure tourism (hiking, cycling) and recreation (geocaching, ropes courses, fitness trails, Nordic walking trails, sleigh, horse-drawn cart and all-terrain vehicle rides) (Kołodyńska-Gawrysiak et al. 2012; Zgłobicki et al. 2012). Currently, the gullies are used for tourism and recreation purposes to a limited extent. Most frequently, they are used for hiking. The tourist traffic is concentrated in just a few gullies located in the immediate vicinity of Kazimierz Dolny.

All-terrain vehicle and quad rides are a popular form of recreation in the gullies. Some of the gullies in the municipality are used for sleigh rides in the winter and horse-drawn cart rides in the summer. Ski slopes with accompanying infrastructure are located in two gullies.

\subsection{Impact of tourism on gullies}

At present, gullies are quite commonly used by people, engaging in active and adventure tourism. In some cases, the uncontrolled development/characteristic of these activities may pose a serious hazard to the gullies. A particular hazard is linked to quad and all-terrain vehicle traffic, which causes damage to the gully sides and floors, and triggers erosion processes, through the degradation of vegetation cover. Current laws do not ensure an efficient protection of gullies against such hazards. Therefore, in the case of particularly valuable areas, it would be advisable to consider establishing nature reserves, i.e. protected areas with higher levels of protection. The fact that some gullies continue to be used as illegal rubbish dumps poses another threat, both to the environment and tourism. Another major difficulty may arise due to the fencing off of gullies and shutting off access to many well known and interesting sites, even in places reached by tourist and walking trails or educational paths. In recent years, numerous measures have been undertaken in the sunken lanes in the Lublin region, in order to protect them against the adverse effects of erosion. These measures are primarily aimed at maintaining the traffic function of the sunken lanes and are based on reinforcing their floors with various materials, mainly openwork concrete slabs. In the context of preventative measures, besides maintaining the passability of sunken lanes, it is also important to preserve their visual value. This requires solutions that will take into account the need for landscape conservation and enable the preservation of the visual and educational value of the gullies.

\subsection{The educational function of gullies: outlook for the future}

Opportunities for the development of geotourism offered by the existence of unique forms of loess relief, particularly gullies, will be a cornerstone of the future Małopolska Vistula 
Gap Geopark. Gullies account for $15 \%$ of the geosites in the proposed geopark. It is essential to obtain funding for building the required infrastructure and promotion of geotourist features. In our opinion, it can be achieved only by establishing a geopark in the study area. It would also be an opportunity to make tourist traffic more balanced, as it is currently focussed on Kazimierz Dolny and its immediate vicinity. What is important is that geotourism is a form of sustainable tourism with a relatively small negative impact on the environment (Hose 1995; Dowling 2013).

They are also among the sites with the highest geotourist value (Warowna et al. 2014). A vast majority of gullies are located in the Kazimierz Dolny municipality, an area with very high tourist traffic (in the order of 1 million people per year) and well-developed tourist infrastructure, with regard to accommodation and catering facilities. What is missing, is the information infrastructure concerning geoheritage, particularly problems related to gully erosion.

The education-related problems presented in this study concern gully erosion in the loess areas, in Poland. It would be advisable to extend similar studies to include other areas, where gullies occur, and to highlight the important educational role that can be played by these geomorphosites. The peculiar geological structure, land relief, and climate conditions, as well as history of agriculture and human settlement, would make it possible to explore the specific determinants of the relationship between human activity and gully erosion. This relationship has been well researched thanks to numerous studies conducted in many European countries: Belgium (Vanwalleghem et al. 2006); Germany (Dotterweich 2005); Poland (Smolska 2007); Romania (Ionita 2006); Slovakia (Dotterweich et al. 2013); Italy (Torri et al. 2013) and Spain (Casalí et al. 1999).

\section{Conclusions}

- The gullies in the Kazimierz Dolny area have considerable geotourist resources that are not fully used, at present.

- The respondents regard gullies as a tourist attraction and visit them quite often, but their knowledge on gully erosion is not always extensive.

- There is a need to educate the public with regard to gully erosion, particularly the significance of these processes to people.

- The most important task is to enhance the educational value of the gullies, by preparing geotourist trails and suitable interpretation boards, that would explain the geomorphological aspects of a particular site, in an accessible way.

- The conflict between making the gullies accessible and protecting them remains a key issue. Intensive tourist traffic, particularly motorised tourists, can pose a major threat to the value of the natural environment.

- It would be advisable to conduct studies assessing the educational values of gullies, in other parts of Europe.

Acknowledgments This study was financed from funds for scientific research, by the Faculty of Earth Sciences and Spatial Management, Maria Curie-Skłodowska University, in Lublin. The authors wish to thank various anonymous reviewers for their valuable comments towards the manuscript.

Open Access This article is distributed under the terms of the Creative Commons Attribution License which permits any use, distribution, and reproduction in any medium, provided the original author(s) and the source are credited. 


\section{Appendix 1: Survey of the students}

1. Are you familiar with the term "loess gully"? Can you define it?

$\square$ yes $\quad \square$ no

2. Have you visited a loess gully more than three times?

$\square$ yes $\square$ no

3. Choose the distinguishing characteristics of a loess gully in Poland from this list

$\square$ narrow floor $\square$ broad floor $\square$ gently sloping sides $\square$ steep sides $\quad \square$ dry floor $\quad \square$ floor with a stream $\square$ covered by forest $\square$ used agriculturally (pastures, plantations)

4. In your opinion, what is the human impact on the formation and development of gullies?
$\square$ small
$\square$ moderate
$\square$ large
$\square$ I do not know

5. The origins of loess gullies (how they form)

$\square$ activity of rivers

$\square$ precipitation and snowmelt runoff in forest areas

$\square$ precipitation and snowmelt runoff in agriculturally used areas

$\square$ direct impact of human activity

$\square$ I do not know

6. Please rank the factors influencing the formation of loess gullies (1: least significant factor, 5 : most significant factor)

... landforms (slope gradients)

... density of the river network

... land cover (land use)

... type of soils and substratum

... annual precipitation volume

6. Please indicate areas with the highest gully density in the Lublin region

$\square$ the Lubartów area

$\square$ the Kazimierz Dolny area

$\square$ the Szczebrzeszyn area

$\square$ the Chełm area

$\square$ I do not know

7. What is the general impact of the formation and development of gullies on human activity
$\square$ no impact at all
$\square$ positive
$\square$ negative
$\square$ I do not know

8. Gully erosion can have the following negative effects on human activity (please select the two most negative effects):

$\square$ reduced acreage of cropland

$\square$ covering of roads, farms and crops with silt

$\square$ increased risk of local flooding

$\square$ reduced crop yields

$\square$ reduced biodiversity

$\square$ I do not know 
9. The following kinds of human activity increase the intensity of gully erosion (please choose three most important ones):

$\square$ use of heavy farming equipment

$\square$ deforestation

$\square$ cultivation of fields in the vicinity of gullies

$\square$ use of gullies as dirt roads

$\square$ cultivation of very steep slopes

$\square$ construction of new houses

$\square$ I do not know

10. The best method for preventing gully erosion in your opinion (please choose one method, taking into account environmental and economic factors)

$\square$ reforestation of gullies and adjacent areas

$\square$ reinforcing the gully floor (concrete slabs, concrete paving blocks)

$\square$ specially designed field and crop pattern in the vicinity of gullies

$\square$ filling in of gullies

11. In your opinion, do loess gullies represent a tourist attraction?

$\square$ yes $\quad \square$ no

12. Name three characteristics that, in your opinion, contribute to the recognition of gullies as places of tourist interest

$\square$ interesting vegetation $\quad \square$ good place for walks $\quad \square$ good place for active tourism

$\square$ interesting objects of inanimate nature $\quad \square$ varied landscapes $\quad \square$ natural character of landscape

13. How many times have you visited the Kazimierz Dolny area as a tourist (over the last five years)?

$\square 0 \quad \square 1-2 \quad \square 3-5 \square \quad \square>5$

\section{Respondent information}

Sex $\quad \square$ female $\quad \square$ male

Study programme $\quad \square$ geography $\square$ tourism and recreation $\square$ geoinformatics

$\square$ spatial management

Year of study I $\square \quad$ II $\square \quad$ III $\square$

Place of permanent residence: $\quad \square$ village $\square$ town of up to 50 thousand

$\square$ town of more than 50 thousand 


\section{Appendix 2: Survey of the tourists}

1. Are you familiar with the term "loess gully"? Can you define it?

$\square$ yes $\quad \square$ no

2. Have you visited a loess gully more than three times?

$\square$ yes $\quad \square$ no

3. Choose the distinguishing characteristics of a loess gully in Poland from this list

$\square$ narrow floor $\quad \square$ broad floor $\quad \square$ gently sloping sides $\quad \square$ steep sides

$\square$ dry floor $\square$ floor with a stream $\quad \square$ covered by forest $\quad \square$ used agriculturally (pastures, plantations)

4. In your opinion, what is the human impact on the formation and development of gullies?
$\square$ small
$\square$ moderate
$\square$ large
$\square$ I do not know

5. Please indicate areas with the highest gully density in Poland

$\square$ Beskidy mountains

$\square$ Lake districts

$\square$ uplands

$\square$ lowlands

6. What is the general impact of the formation and development of gullies on human activity
$\square$ no impact at all
$\square$ positive
$\square$ negative
$\square$ I do not know

7. The best method for preventing gully erosion in your opinion (please choose one method, taking into account environmental and economic factors)

$\square$ reforestation of gullies and adjacent areas

$\square$ reinforcing the gully floor (concrete slabs, concrete paving blocks)

$\square$ specially designed field and crop pattern in the vicinity of gullies

$\square$ filling in of gullies

8. In your opinion, do loess gullies represent a tourist attraction?

$\square$ yes $\square$ no

9. Name three characteristics that, in your opinion, contribute to the recognition of gullies as places of tourist interest

$\square$ interesting vegetation $\quad \square$ good place for walks $\quad \square$ good place for active tourism

$\square$ interesting objects of inanimate nature $\quad \square$ varied landscapes $\quad \square$ natural character of landscape

10. How many times have you visited the Kazimierz Dolny area as a tourist (over the last five years)?

$\square 0 \quad \square 1-2 \quad \square 3-5 \square \quad \square>5$

\section{Respondent information}

Sex $\square$ female $\square$ male

Place of permanent residence: $\quad \square$ village $\square \square$ town of up to 50 thousand

$\square$ town of more than 50 thousand.

Province: 


\section{References}

Baran-Zgłobicka B, Zgłobicki W (2012) Mosaic landscapes of SE Poland: should we preserve them? Agrofor Syst 85:351-365

Casalí J, López JJ, Giráldez JV (1999) Ephemeral gully erosion in southern Navarra (Spain). Catena 36:65-84

Coratza P, De Waele J (2012) Geomorphosites and natural hazards: teaching the importance of geomorphology in society. Geoheritage 4:195-203

Dong H, Song Y, Chen T, Zhao J, Yu L (2014) Geoconservation and geotourism in Louchan Loess National Geopark, China. Quat Int 334-335:40-51

Dotterweich M (2005) High resolution reconstruction of a 1300 years old gully system in northern Bavaria, Germany as a basis for modelling long term man induced landscape evolution. Holocene 15(7):994-1005

Dotterweich M, Rodzik J, Zgłobicki W, Schmitt A, Schmidtchen G, Bork H-R (2012) High resolution gully erosion and sedimentation processes, and land use changes since the Bronze Age and future trajectories in the Kazimierz Dolny area (Nałęczów Plateau, SE-Poland). Catena 95:50-62

Dotterweich M, Stankoviansky M, Minár J, Koco S, Papčo P (2013) Human induced soil erosion and gully system development in the Late Holocene and future perspectives on landscape evolution: the Myjava Hill Land, Slovakia. Geomorphology 201:227-245

Dowling RK (2013) Global geotourism - an emerging form of sustainable tourism. Czech J Tour 2(2):59-79

Dunbar PK (2007) Increasing public awareness of natural hazards via the Internet. Nat Hazard 42:529-536

Farsani NT, Coelho COA, Costa CMM, Amrikazemi A (2014) Geo-knowledge management and geoconservation via geoparks and geotourism. Geoheritage 6(3):185-192

Gardziel Z, Harasimiuk M, Jezierski W, Pawłowski A, Zgłobicki W (2006) Erozja wąwozowa w zachodniej części Płaskowyżu Nałęczowskiego. Przegląd Geologiczny 54:768-776

Gawrysiak L, Harasimiuk M (2012) Zróżnicowanie przestrzenne gęstości wąwozów na Wyżynie Lubelskiej i Roztoczu. Annales UMCS B 67:27-43

Hose TA (1995) Selling the story of Britain's stone. Env Interpret 10(2):16-17

Ionita I (2006) Gully development in the Moldavian Plateau of Romania. Catena 68(2-3):133-140

Kołodyńska-Gawrysiak R, Gawrysiak L, Zgłobicki W, Jezierski W (2012) Ocena wykorzystania potencjału turystycznego i rekreacyjnego wąwozów lessowych w gminie Kazimierz Dolny. Problemy Ekologii Krajobrazu 34:87-93

Maruszczak H (1986) Tendencje sekularne i zjawiska ekstremalne w rozwoju rzeźby małopolskich wyżyn lessowych w czasach historycznych. Czasopismo Geograficzne 57:271-282

Poesen J, Nachtergaele J, Verstraeten G, Valentin C (2003) Gully erosion and environmental change: importance and research needs. Catena 50(2-4):91-133

Poesen J, Vanwalleghem T, de Vente J, Knapen A, Verstraeten G, Martinez-Casasnovas JA (2006) Gully erosion in Europe. In: Boardman J, Poesen J (eds) Soil erosion in Europe. Wiley, Chichester, pp 515-536

Rodzik J, Janicki G, Zagórski P, Zgłobicki W (1998) Deszcze nawalne na Wyżynie Lubelskiej i ich wpływ na rzeźbę obszarów lessowych. Dokumentacja Geograficzna 11:45-68

Rodzik J, Furtak T, Zgłobicki W (2009) The impact of snowmelt and heavy rainfall runoff on erosion rates in a gully system, Lublin Upland, Poland. Earth Surf Proc Landf 34:1938-1950

Schmitt A, Rodzik J, Zgłobicki W, Russok Ch, Dotterweich M, Bork H-R (2006) Time and scale of gully erosion in the Jedliczny Dol gully system, south-east Poland. Catena 68:124-132

Serrano E, Gonzales-Trueba JJ (2005) Assessment of geomorphosites in natural protected areas: the Picos de europa national park (Spain). Géomorphologie: relief, processus, environment 3/2005:197-208

Smolska E (2007) Development of gullies and sediment fans in last-glacial areas on the example of the Suwałki Lakeland (NE Poland). Catena 71:122-131

Solarska A, Hose T, Vasiljević DA, Mroczek P, Jary Z, Marković SB, Widawski K (2013) Geodiversity of loess regions in Poland: inventory, geoconservation issues, and geotourism potential. Quat Int 296:68-81

Thomas MF (2012) A geomorphological approach to geodiversity-its applications to geoconservation and geotourism. Quaest Geogr 31(1):81-89

Torri D, Santi E, Marignani M, Rossi M, Borselli L, Maccherini S (2013) The recurring cycles of biancana badlands: erosion, vegetation and human impact. Catena 106:22-30

Valentin C, Poesen J, Li Y (2005) Gully erosion: impacts, factors and control. Catena 63(2-3):132-153

Vanwalleghem T, Bork H-R, Poesen J, Dotterweich M, Schmidtchen G, Deckers J, Scheers S, Martens M (2006) Prehistoric and roman gullying in the European loess belt: a case study from central Belgium. Holocene 16(3):393-401 
Warowna J, Migoń P, Kołodyńska Gawrysiak R, Kiebała A, Zgłobicki W (2013) Geomorphosites of Poland-the role played by the central register of geosites. Landf Anal 22:117-124

Warowna J, Zgłobicki W, Gajek G, Telecka M, Kołodyńska-Gawrysiak R, Zieliński P (2014) Geomorphosite assessment in the proposed geopark vistula river gap (E Poland). Quaest Geogr 33(3):173-180

Zgłobicki W, Baran-Zgłobicka B (2011) Gullies as an indicator of human impact on loess landscape (case study: north western part of Lublin Upland, Poland). Zeitschrift für Geomorphologie 55(1):119-137

Zgłobicki W, Baran-Zgłobicka B (2012) Impact of loess relief on land use mosaic in SE Poland. Catena 96:76-82

Zgłobicki W, Baran-Zgłobicka B (2013) Geomorphological heritage as a tourist attraction. A case study in Lubelskie Province, SE Poland. Geoheritage 5:137-149

Zgłobicki W, Kołodyńska-Gawrysiak R, Gawrysiak L, Pawłowski A (2012) Walory geoturystyczne rzeźby lessowej zachodniej części Wyżyny Lubelskiej. Przegląd Geologiczny 60(1):26-31 